\title{
UJI AKTIVITAS ANTIBAKTERI EKSTRAK DAUN TEMBELEKAN (Lantana camara Linn) TERHADAP PERTUMBUHAN Staphylococcus aureus dan Escherichia coli
}

\section{Antibacterial Activity Test of Tembelekan (Lantana camara Linn) Leaf Extracts on the growth of Staphylococcus aureus and Escherichia coli}

\author{
Gaby Maulida Nurdin $^{1 *}$, Aprisal $^{2}$, Nur Amalia $^{1}$, dan Masyitha Wahid ${ }^{1}$ \\ ${ }^{1}$ Prodi Pendidikan Biologi Fakultas Keguruan dan IImu Pendidikan Universitas Sulawesi Barat, \\ Majene, Sulawesi Barat 91214 \\ ${ }^{1}$ Prodi Pendidikan Matematika Fakultas Keguruan dan IImu Pendidikan Universitas Sulawesi \\ Barat, Majene, Sulawesi Barat 91214
}

\begin{abstract}
Keywords:
ABSTRACT

Tembelekan leaf (Lantana camara Linn), antibacterial, Staphylococcus aureus, Escherichia coli.

This study aimed to determine the effect of concentration ethanol extract from tembelakan leaf (Lantana camara Linn) on bacteria growth of Staphylococcus aureus and Escherichia coli. Extraction was done by maceration using ethanol $96 \%$ and then separated using rotary evaporator. Antibacterial activity test of the ethanol extract by Well agar diffusion method. Variation in crude extract saponin used in this study was $5 \%, 10 \%, 15 \%, 20 \%, 25 \%$ and positive controls were used for comparison with Amoxicilin and Chloramphenicole concentration of $25 \mu \mathrm{g} / \mathrm{mL}$ and DMSO as a negative control. The results of antibacterial activity test is indicated by the formation of growth inhibitory region S. aureus and E. coli. The result of growth inhibitory regions was analyzed by One way ANOVA. One way ANOVA test results indicate that there are effects of ethanol extract concentration of tembelekan leaf (L. camara Linn) against $S$. aureus and $E$. coli. Effective concentration of ethanol extract tembelekan leaf ( $L$. camara Linn) when compared with positive control to inhibit the growth of $S$. aureus and $E$. coli is at $25 \%$ with a relatively strong antibacterial activity. Test with phytochemicals screening method which is showed that tembelekan leaf contains the flavanoid, saponins, and tannins compounds as antibacterial.
\end{abstract}

\section{Kata Kunci: \\ Tembelekan \\ (Lantana camara \\ Linn), antibakteri, \\ Staphylococcus \\ aureus, Escherichia \\ coli.}

\begin{abstract}
ABSTRAK
Penelitian ini bertujuan untuk mengetahui pengaruh konsentrasi ekstrak etanol dari daun tembelakan (Lantana camara Linn) tehadap pertumbuhan bakteri Staphylococcus aureus dan Escherichia coli. Ekstraksi dilakukan dengan cara maserasi menggunakan pelarut etanol $96 \%$ kemudian diuapkan menggunakan rotary evaporator. Uji aktivitas antibakteri ekstrak dengan cara metode difusi agar sumuran. Variasi ekstrak yang digunakan adalah 5\%, 10\%, 15\%, 20\%, dan 25\% dengan kontrol positif sebagai pembanding adalah amoksisilin dan kloramfenikol konsentrasi $25 \mu \mathrm{g} / \mathrm{mL}$ dan Dimetil Sulfoksida (DMSO) sebagai kontrol negatif. Hasil uji aktivitas antibakteri ditunjukkan dengan terbentuknya zona hambatan pertumbuhan $S$. aureus dan $E$. coli. Data daerah hambat pertumbuhan yang diperoleh diuji One way anova. Jika ada perbedaan dilanjutkan uji Tukey HSD. Data hasil uji One way anova menunjukkan bahwa ada pengaruh konsentrasi ekstrak etanol daun tembelekan (L. camara Linn) terhadap S. aureus dan E. coli. Konsentrasi efektif ekstrak etanol daun tembelekan (L. camara Linn) jika dibandingkan dengan kontrol positif untuk menghambat pertumbuhan bakteri $S$. aureus dan E. coli adalah pada $25 \%$ dengan aktivitas antibakteri yang tergolong kuat. Uji golongan dengan metode skrining fitokimia menunjukkan bahwa daun tembelekan mengandung senyawa flavanoid, saponin, dan tanin yang bersifat antibakteri.
\end{abstract}

Corresponding Author : gabymaulidanurdin@unsulbar.ac.id 


\section{PENDAHULUAN}

Staphylococcus aureus dan Escherichia coli merupakan bakteri patogen yang paling banyak menyerang manusia. S. aureus merupakan bakteri patogen Gram-positif yang bersifat invasif dan merupakan flora normal pada kulit, mulut, dan saluran nafas manusia. $S$. aureus merupakan patogen paling utama pada kulit (Harahap, 2002). S. aureus menyebabkan meningitis, infeksi kulit, dan pneumonia (Jawetz et al., 2005). Bakteri E. coli adalah bakteri Gram negatif yang merupakan flora normal di usus manusia yang dapat menyebabkan Infeksi Saluran Kencing (ISK) dan diare (Jawetz et al., 2005)

Berbagai terapi pengobatan telah dilakukan untuk mengobati penyakit yang disebabkan oleh bakteri, khususnya menggunakan berbagai jenis antibiotik. Namun, menurut Aibinu, et al. (2007) beberapa tahun belakangan ini telah terdapat peningkatan strain patogen yang resisten terhadap antibiotik. Hal ini menyebabkan munculnya strain bakteri baru yang multi-resisten. Timbulnya resistensi bahkan multiresistensi dari populasi bakteri terhadap berbagai jenis antibiotik menimbulkan banyak masalah dalam pengobatan penyakit infeksi (Haryati et al., 2015). Sehingga diperlukan usaha untuk mengembangkan obat tradisional yang berasal dari tanaman yang memiliki daya kerja optimal dan tidak resisten terhadap bakteri. WHO (2003) juga mendukung upaya-upaya dalam peningkatan keamanan dan khasiat dari obat tradisional yang berasal dari tumbuhan. Pemanfaatan tumbuhan sudah dilakukan oleh masyarakat sejak masa sebelum masehi hingga sekarang, namun belum banyak yang dibuktikan aktivitasnya ISSN-P : 1978-6417; ISSN-E : 2580-5991 secara ilmiah (Hertiani et al., 2003). Salah satu tumbuhan yang telah terbukti secara empiris sebagai antibakteri adalah tembelekan (Lantana camara L).

Tumbuhan Tembelekan (Lantana camara L) merupakan tumbuhan liar yang tumbuh di berbagai tempat. Tumbuhan ini digunakan masyarakat untuk mengobati beberapa macam penyakit seperti luka, batuk, luka, peluruh haid, penurun panas, obat bengkak, encok dan bisul (Suwertayasa, et al., 2013). Menurut Hidayati (2005), daun tembelekan ( $L$. camara Linn) juga mengandung saponin, flavanoid dan minyak atsiri. Senyawa flavonoid telah dikenal memiliki efek anti inflamasi. Hal ini sejalan dengan penelitian Parwanto (2013) yang melaporkan bahwa Tembelekan ( $L$. camara L) memiliki kandungan kimia antara lain fenol, flavonoid dan alkaloid. Kandungan kimia pada Tembelekan diduga memiliki kemampuan antibakteri terhadap Staphylococcus epidermidis.

Tujuan dari penelitian ini adalah untuk menguji aktivitas antibakteri ekstrak etanol daun Tembelekan (L. camara Linn) terhadap pertumbuhan Staphyloccocus aureus yang merupakan bakteri Gram positif dan Escherichia coli yang merupakan bakteri Gram negatif. Konsentrasi ekstrak yang diuji adalah 5\%, 10\%, 15\%, 20\%, dan $25 \%$. Pengujian yang dilakukan meliputi uji antibakteri dan uji senyawa aktif.

\section{BAHAN DAN METODE}

Penelitian dilaksanakan pada bulan Februari - April 2021. Tahapan penelitian meliputi (1) Tahapan persiapan dan pengolahan sampel, (2) Ekstraksi dan persiapan konsentrasi, (3) Uji aktivitas antimikroba daun tembelakan dan (4) Uji 
golongan senyawa aktif, (5) Tahapan analisis data.

\section{Tahapan Persiapan dan Pengolahan} Sampel

Sampel daun diambil dari tumbuhan tembelekan (Lantana camara Linn) yang masih segar diperoleh di wilayah Kota Makassar, Propinsi Sulawesi Selatan. Sampel daun selanjutnya dicuci bersih dan dikeringanginkan di bawah sinar matahari. Daun yang telah kering ditimbang dan dipotong-potong ukuran kecil sebesar $0,2 \mathrm{~cm}$.

\section{Ekstraksi dan Persiapan Konsentrasi}

Sebanyak 100 gram simplisia diekstrasi dengan 1 liter etanol 96\% secara maserasi. Ekstrak disaring dan diuapkan dengan rotary evaporator hingga diperoleh ekstrak etanol kental. Hasil ekstrak yang diperoleh, kemudian dibuatkan variasi konsentrasi $5 \%$, $10 \%, 15 \%, 20 \%$, dan $25 \%$. Sebagai kontrol positif menggunakan antibiotik amoksisilin dan kloramfenikol, serta Dimetil Sulfoksida (DMSO) sebagai kontrol negatif.

\section{Uji Aktivitas Animikroba}

Pengujian dilakukan secara in vitro dengan metode difusi agar dengan menggunakan metode lubang atau sumur (hole, well). Sebanyak $200 \mu \mathrm{l}$ masing-masing larutan ekstrak konsentrasi 5\%, 10\%, 15\%, 20\%, dan $25 \%$. Kontrol positif menggunakan antibiotik Amoksisillin $25 \mu \mathrm{g}$ untuk bakteri uji $S$. aureus dan Kloramfenikol $30 \mu \mathrm{g}$ untuk bakteri uji $E$. coli. Sedangkan kontrol negatif menggunakan DMSO (Dimetil sulfoksida) yang masing-masing konsentrasi dan kontrol diisi kedalam setiap sumur. Cawan petri diinkubasi dalam inkubator selama 24 - 48 jam pada suhu 37 ${ }^{\circ} \mathrm{C}$. Setelah masa inkubasi tersebut, diukur diameter zona hambatan pertumbuhan bakteri di sekeliling sumuran dengan menggunakan jangka sorong.

\section{Uji Golongan Senyawa Aktif}

Uji golongan senyawa steroid dilakukan sesuai dengan metode Harborne, uji senyawa flavanoid dan tanin berdasarkan metode Farnsworth, dan uji senyawa saponin dilakukan dengan metode Teyler.

\section{Analisis Data}

Data dianalisis secara deskriptif dengan melihat diameter zona hambatan yang dihasilkan dan kemudian diklasifikasikan kemampuan hambatan berdasarkan Tabel 1

Tabel 1. Klasifikasi respon hambat pertumbuhan bakteri (Surwardjo et al.,2015)

\begin{tabular}{cc}
\hline Diameter Zona Terang & Respon Hambatan Pertumbuhan \\
\hline$\geq 21 \mathrm{~mm}$ & Sangat Kuat \\
\hline $11-20 \mathrm{~mm}$ & Kuat \\
\hline $6-10 \mathrm{~mm}$ & Sedang \\
$\leq 5 \mathrm{~mm}$ & Lemah
\end{tabular}

\section{HASIL}

Hasil pengukuran diameter hambatan menunjukkan bahwa pada semua konsentrasi ekstrak etanol tembelekan ( $L$. ISSN-P : 1978-6417; ISSN-E : 2580-5991 camara Linn) memiliki aktivitas antimikroba terhadap Staphylococcus aureus dan Escherichia coli yang ditandai dengan 


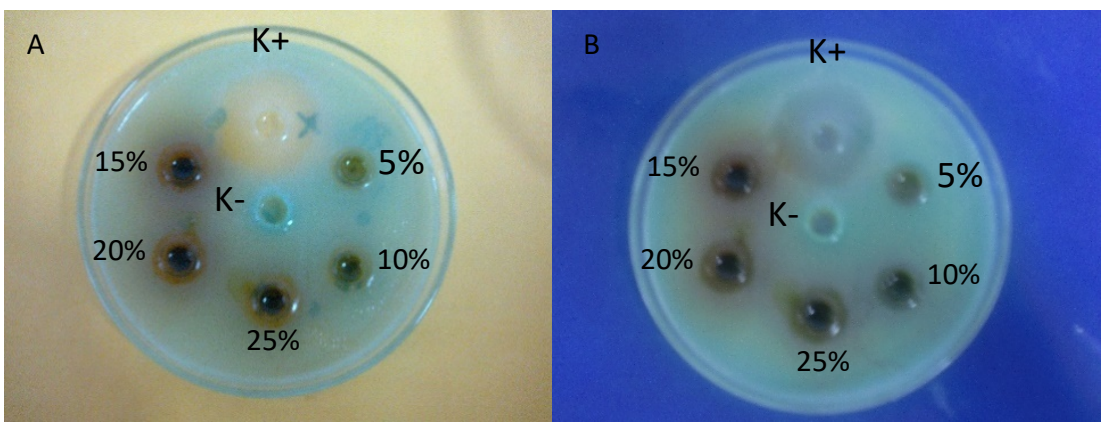

Gambar 1. Hasil uji daya hambat ekstrak etanol tembelekan (L. camara Linn) terhadap pertumbuhan bakteri S. aureus (A) dan E. coli (B) setelah masa inkubasi 24 jam

Gambar 1 menunjukkan bahwa diameter zona hambat tertinggi pada bakteri Staphylococcus aureus dan Escherichia coli dengan masa inkubasi 24 jam ditunjukkan pada konsentrasi $25 \%$ dengan diameter daya hambat masing-masing 16,5 dan 12,1 mm. Kemudian konsentrasi $20 \%, 15 \%$,
$10 \%$ dan yang paling kecil yaitu $5 \%$ antara 11,8 dan $9,5 \mathrm{~mm}$ pada $S$. aureus dan $E$. coli. Setelah masa inkubasi 48 jam, masingmasing dari tingkat konsentrasi tersebut ada yang mengalami peningkatan dan penurunan zona hambat. Selengkapnya dapat diamati pada tabel 2

Tabel 2. Hasil pengukuran diameter zona hambatan ekstrak daun tembelekan (L. camara Linn) pada bakteri S. aureus dan E. coli dengan masa inkubasi 24 dan 48 jam.

\begin{tabular}{|c|c|c|c|c|}
\hline \multirow{3}{*}{$\begin{array}{l}\text { Konsentrasi } \\
\text { Ekstrak }\end{array}$} & \multicolumn{4}{|c|}{ Diameter Zona Hambatan (mm) Pada Bakteri Uji } \\
\hline & \multicolumn{2}{|c|}{ Staphylococcus aureus } & \multicolumn{2}{|c|}{ Escherichia coli } \\
\hline & 24 jam & 48 jam & 24 jam & 48 jam \\
\hline \multirow[t]{2}{*}{$5 \%$} & 12,4 & 12,4 & 9,2 & 8 \\
\hline & 11,3 & 11,3 & 9,7 & 8,2 \\
\hline$\overline{\boldsymbol{X}} \pm \mathrm{SD}$ & $11,8 \pm 0,5$ & $11,8 \pm 0,5$ & $9,5 \pm 0,2$ & $8.1 \pm 0,1$ \\
\hline \multirow[t]{2}{*}{$10 \%$} & 13,8 & 13,8 & 10,3 & 8,7 \\
\hline & 12,2 & 12,2 & 11,6 & 9,1 \\
\hline$\overline{\boldsymbol{X}} \pm \mathrm{SD}$ & $13 \pm 0,8$ & $13 \pm 0,8$ & $10,9 \pm 0,6$ & $8.9 \pm 0,2$ \\
\hline \multirow[t]{2}{*}{$15 \%$} & 15,3 & 15,3 & 11,4 & 9,0 \\
\hline & 14,7 & 14,7 & 12,0 & 9,6 \\
\hline$\overline{\boldsymbol{X}} \pm \mathrm{SD}$ & $15 \pm 0,3$ & $15 \pm 0,3$ & $11,7 \pm 0,3$ & $8 \pm 0,3$ \\
\hline \multirow[t]{2}{*}{$20 \%$} & 16,5 & 17,1 & 12,5 & 9,8 \\
\hline & 15,9 & 16,9 & 13,2 & 9,9 \\
\hline$\overline{\boldsymbol{X}} \pm \mathrm{SD}$ & $16,2 \pm 0,3$ & $17 \pm 0,1$ & $12,9 \pm 0,3$ & $9.3 \pm 0,1$ \\
\hline \multirow[t]{2}{*}{$25 \%$} & 17,0 & 18,4 & 12,8 & 9,5 \\
\hline & 16,1 & 16,3 & 11,4 & 9,0 \\
\hline$\overline{\boldsymbol{X}} \pm \mathrm{SD}$ & $16,5 \pm 0,4$ & $17,3 \pm 1,0$ & $12,1 \pm 0,7$ & $9,8 \pm 0,2$ \\
\hline \multirow[t]{2}{*}{ Kontrol (+) } & 23,4 & 28,2 & 18,7 & 13,2 \\
\hline & 22,8 & 27,6 & 17,9 & 12,0 \\
\hline$\overline{\boldsymbol{X}} \pm \mathrm{SD}$ & $23,1 \pm 0,3$ & $27,9 \pm 0,3$ & $18,3 \pm 0,4$ & $9.2 \pm 0,6$ \\
\hline \multirow[t]{2}{*}{ Kontrol (-) } & 0 & 0 & 0 & 0 \\
\hline & 0 & 0 & 0 & 0 \\
\hline$\overline{\boldsymbol{X}} \pm \mathrm{SD}$ & $0 \pm 0,0$ & $0 \pm 0,0$ & $0 \pm 0,0$ & $0 \pm 0,0$ \\
\hline
\end{tabular}

ISSN-P : 1978-6417; ISSN-E : 2580-5991 
Pada tabel 2 di atas menunjukan bahwa uji daya hambat pada konsentrasi $5 \%, 10 \%$, $15 \%$, $20 \%$, dan $25 \%$ terjadi hambatan yang ditandai dengan adanya zona bening disekitar sumur. Masing-masing zona bening memiliki diameter yang berbeda seiring dengan meningkatnya konsentrasi. Nampak bahwa semakin tinggi konsentrasi maka semakin besar pula daya hambatnya. Namun, pada inkubasi 48 jam kemampuan penghambatan ekstrak daun tembelekan ( $L$. camara Linn) meningkat pada bakteri $S$. aureus, sedangkan pada bakteri E.coli mengalami penurunan. Hal ini menunjukkan bahwa ekstrak daun tembelakan ( $L$. camara Linn) bersifat bakteriosidal terhadap S.aureus dan bakteriostatik terhadap E.coli. Perbedaan besarnya zona hambatan untuk masing-masing konsentrasi dapat diakibatkan karena perbedaan besarnya kandungan zat aktif dan reaksi antara bahan aktif dengan medium.

Tabel 3 Klasifikasi Respon Hambatan Tiap Konsentrasi Ekstrak Daun Tembelakan (L. camara Linn) terhadap Bakteri Staphylococcus aureus

\begin{tabular}{ccc}
\hline Seri Konsentrasi & $\begin{array}{c}\text { Rata-rata Zona } \\
\text { Hambatan }(\mathrm{mm}) \pm \text { SD }\end{array}$ & Respon Hambatan \\
\hline $5 \%$ & $11,8 \pm 0,5$ & Kuat \\
\hline $10 \%$ & $13 \pm 0,8$ & Kuat \\
\hline $15 \%$ & $15 \pm 0,3$ & Kuat \\
\hline $20 \%$ & $16,2 \pm 0,3$ & Kuat \\
\hline $25 \%$ & $16,5 \pm 0,4$ & Kuat \\
\hline Kontrol $(+)$ & $23,1 \pm 0,3$ & Sangat Kuat \\
\hline
\end{tabular}

Tabel 4 Klasifikasi Respon Hambatan Tiap Konsentrasi Ekstrak Daun Tembelakan (L. camara Linn) terhadap Bakteri Escherichia coli

\begin{tabular}{ccc}
\hline Seri Konsentrasi & $\begin{array}{c}\text { Rata-rata Zona } \\
\text { Hambatan }(\mathrm{mm}) \pm \text { SD }\end{array}$ & Respon Hambatan \\
\hline $5 \%$ & $9,5 \pm 0,2$ & Sedang \\
\hline $10 \%$ & $10,9 \pm 0,6$ & Sedang \\
\hline $15 \%$ & $11,7 \pm 0,3$ & Kuat \\
\hline $20 \%$ & $12,9 \pm 0,3$ & Kuat \\
\hline $25 \%$ & $12,1 \pm 0,7$ & Kuat \\
\hline Kontrol $(+)$ & $18,3 \pm 0,4$ & Kuat \\
\hline
\end{tabular}

Tabel 3 menunjukkan pemberian lima konsentrasi ekstrak etanol daun tembelekan (L. camara Linn) memiliki respon hambatan terhadap $S$. aureus dalam kategori kuat dibandingkan dengan kontrol negatif. Namun, respon hambatan kontrol positif yakni antibiotik amoksisilin masih lebih kuat dibandingkan konsentrasi ekstrak. Respon hambatan bakteri E.coli di tabel 4 menunjukkan bahwa konsentrasi ekstrak $5 \%$ dan $10 \%$ memiliki aktifitas penghambatan tergolong sedang. Sedangkan konsentrasi lainnya memiliki respon hambatan yang kuat sama seperti 
kontrol positif yang menggunakan kloramfenikol. Dari hasil yang diperoleh terlihat bahwa ekstrak etanol daun tembelekan (L. camara Linn) lebih efektif menghambat pertumbuhan bakteri Gram positif yaitu $S$. aureus dibanding bakteri Gram negatif yaitu E. coli. Hal ini disebabkan adanya kemampuan biologis setiap bakteri yang berbeda dalam merespon bahan antibakteri. Salah satu faktor yang paling berpengaruh adalah adanya perbedaan struktur dinding sel antara bakteri Gram negatif dan bakteri Gram positif. Susunan dinding sel bakteri Gram positif terdiri atas $90 \%$ lapisan peptidoglikan dan lapisan tipis lainnya yaitu asam teikoat (Fardiaz, 1989). Perbedaan aktivitas hambatan bakteri juga dipengaruhi oleh senyawa aktif kosentrasi yang tersaring dan adanya bahan organik asing dapat menurunkan keefektifan zat kimia antimicrobial dengan cara menonaktifkan bahan kimia tersebut (Pelczar dan Chan, 1988).

Berdasarkan hasil pemaparan di atas terlihat bahwa ada pengaruh konsentrasi ekstrak etanol daun tembelekan (L. camara Linn) terhadap S. aureus dan E.coli. Hal ini juga diperkuat dengan uji perbedaan rata-rata diameter zona hambat konsentrasi ekstrak etanol daun tembelekan (L. camara Linn) terhadap S. aureus dan E.coli dapat dilihat pada Tabel 5 berikut.

Tabel 5. Hasil Uji Perbedaan Diameter Zona Hambat Konsentrasi Ekstrak Daun Tembelakan (L. camara Linn) terhadap Bakteri Staphylococcus aureus dan Escherichia coli

\begin{tabular}{lc}
\hline \multicolumn{1}{c}{ Klasifikasi } & $p$-value (sig.) \\
\hline Jenis Bakteri & 0.000 \\
\hline Konsentrasi Ekstrak Daun Tembelekan & 0.000 \\
\hline
\end{tabular}

Hasil uji menunjukkan p-value 0.000 dengan konsentrasi $20 \%$ dan $25 \%$. Hal ini lebih kecil dari alpha 0.05. Hal ini menandakan bahwa konsentrasi ekstrak menandakan bahwa terdapat perbedaan diameter zona hambat ditinjau dari besar konsentrasi ekstrak etanol dari daun tembelakan (Lantana camara Linn) dan jenis bakteri yang diuji. Kemudian dilanjutkan dengan uji Tukey yang menunjukkan hasil terdapat perbedaan yang signifikan diameter zona hambat konsentrasi ekstrak etanol dari daun tembelekan (Lantana camara Linn) $5 \%$ etanol dari daun tembelekan (Lantana camara Linn) 5\% mempunyai respon hambat paling kecil terhadap kedua jenis bakteri.

Adanya zona hambat dari kedua bakteri uji mengindikasikan adanya senyawa aktif pada daun tembelekan (L. camara Linn) yang ditunjukkan pada tabel 6. 
Nurdin, dkk. Biocelebes. Desember. 2021. Vol. 15 No. 2, 90-97

Tabel 6. Hasil Uji Golongan ekstrak etanol daun tembelekan (L. camara Linn)

\begin{tabular}{clcc}
\hline \multirow{2}{*}{ Senyawa Aktif } & Hasil Identifikasi \\
\cline { 2 - 4 } & Warna Ekstrak & $\begin{array}{c}\text { Warna yang } \\
\text { Terbentuk }\end{array}$ & Hasil \\
\hline Flavanoid & Hijau Kehitaman & Orange & + \\
\hline Steroid & Hijau Kehitaman & Hijau kehitaman & - \\
\hline Saponin & Hijau Kehitaman & Terbentuk busa & + \\
\hline Tanin & Hijau Kehitaman & Hijau Kehitaman & + \\
\hline
\end{tabular}

Berdasarkan tabel 6, ekstrak etanol daun tembelekan ( $L$. camara Linn) berbagai konsentrasi mampu menghambat pertumbuhan bakteri $S$. aureus dan E. coli dengan respon yang sedang dan kuat. Hal ini dikarenakan adanya senyawa aktif berupa flavonoid, saponin, dan tanin pada ekstrak yang bersifat antibakteri. Flavonoid mempunyai aktivitas antibakteri dengan cara mengganggu fungsi metabolisme mikroorganisme dengan merusak dinding sel dan mendenaturasi protease sel mikroorganisme (Pelczar dan Chan, 1988). Kerusakan tersebut memungkinkan nukleotida dan asam amino merembes keluar dan mencegah masuknya bahanbahan aktif ke dalam sel, sehingga menyebabkan kematian bakteri. Tanin mempunyai aktivitas antibakteri melalui aksi molekulernya yaitu dengan membentuk kompleks dengan protein melalui ikatan hidrogen dan ikatan hidrofobik (Cowan, 1999; Ningsih et al., 2013). Sementara itu senyawa metabolit sekunder. Flavonoid dapat menghambat bakteri yaitu dengan merusak membran sitoplasma yang dapat menyebabkan bocornya metabolit penting dan menginaktifkan sistem enzim bakteri.

Tumbuhan tembelekan (L. camara Linn) dengan pertumbuhannya yang cepat dalam waktu yang singkat merupakan potensi yang luar biasa. Terkhusus tumbuhan ini masih dianggap sebagai ISSN-P : 1978-6417; ISSN-E : 2580-5991 gulma. Berdasarkan hasil penelitian yang diperoleh oleh penulis, maka tumbuhan tembelekan ( $L$. camara Linn) memiliki potensi antibakteri yang tergolong kuat pada bakteri patogen $S$. aureus dan E. coli. Potensi tersebut secara ilmiah dapat dikembangkan untuk mencari potensi lainnya seperti antifungi dan anticancer.

\section{SIMPULAN}

Ekstrak etanol tembelekan (Lantara camara Linn) bersifat antibakteri. Seluruh konsentrasi ekstrak mampu menghambat pertumbuhan bakteri $S$. aureus dan $E$. coli dengan respon yang sedang dan kuat, dengan aktivitas terbesar pada konsentrasi ekstrak 25\%. Berdasarkan ativitas antibakterinya, ekstrak daun tembelakan ( $L$. camara Linn) bersifat bakteriosidal terhadap S.aureus dan bakteriostatik terhadap E.coli. Senyawa aktif yang terkandung pada ekstrak etanol daun tembelekan (Lantara camara Linn) yang diuji dengan menggunakan metode skrining fitokimia menunjukkan adanya senyawa flavanoid, saponin, dan tanin yang bersifat antibakteri.

\section{DAFTAR PUSTAKA}

Aibinu, I.E, Akinsulire, O.R., Adenipekun, T., Adelowotan, T., Odugbemi, T. 2007. In Vitro Antimicrobial Activity of Crude Extracts from Plants Bryophyllum pinnatum and Kalanchoe crenata. African Journal Traditional, 
Complementary and Alternative Medicines Vol.3: 338 - 344.

Cowan, M. M. 1999. Plant Product as Antimicrobial Agents. Clinical Microbiology Reviews, 12 (4): 564582.

Haryati, N.A., Saleh, C., Erwin. 2015. Uji Toksisitas dan Aktivitas Antibakteri Ekstrak Daun Merah Tanaman Pucuk Merah (Syzygium myrtifolium Walp.) terhadap Bakteri Staphylococcus aureus dan Escherichia coli. Jurnal Kimia Mulawarman,13 (1), 35-40.

Harahap, M. 2002. IImu Penyakit Kulit. Hipokrates. Jakarta.

Hidayati, N.A., Listyawati, S., Setyawan, A.D. 2008. Kandungan Kimia dan Uji Antiinflamasi Ekstrak Etanol Lantana camara L. pada Tikus Putih (Rattus norvegicus L.) Jantan. Bioteknologi, 5(1), 10-17.

Jawetz, E., J.L, Melnick dan E.A, Adelberg. 2005. Mikrobiologi Untuk Profesi Kesehatan Edisi 4. Diterjemahkan oleh Bonang, G. Buku Kesehatan Jakarta.

Ningsih, A.P., Nurmiati, Agustien, A. 2013. Uji Aktivitas Antibakteri Ekstrak Kental Tanaman Pisang Kepok Kuning (Musa paradisiaca Linn.) terhadap Staphylococcus aureus dan Escherichia coli Antibacterial Activity of Crude Extracts of Pisang Kepok Kuning (Musa paradisiaca Linn.) Against Staphylococcus aureus and Escherichia coli. Jurnal Biologi Universitas Andalas (J. Bio. UA.) 2(3), 207-213.
Parwanto, M.L.E., Senjaya, H., Edy, H.J. 2013. Formulasi Salep Antibakteri Ekstrak Etanol Daun Tembelekan (Lantana camara L). PHARMACON Jurnal Ilmiah Farmasi - UNSRAT, 2(3), 104-108.

Pelczar, M. J., Chan, E. C. S. 1988. DasarDasar Mikrobiologi. Jakarta: Universitas Indonesia Press.

Surwardjo P., Susilorini T. E., \& Sirait G. R. B. 2015. Daya Hambat Dekok Kulit Apel Manalagi (Malus sylvestrs Mill.) Terhadap

Pertumbuhan Staphylococcus aureus dan Pseudemonas sp. Penyebab Masititis Pada Sapi Perah. Jurnal Ternak Tropika.16 (2), 11-21.

Suwertayasa, I.M.P., Bodhy, W., Edy, H.J. 2013. Uji Efek Antipiretik Ekstrak Etanol Daun Tembelekan (Lantana camara L.) Pada Tikus Putih Jantan Galur Wistar. PHARMACON Jurnal IImiah Farmasi - UNSRAT, 2 (3), 45-49.

WHO. 2003. Traditional Medicine, http://www.who.int/mediacentre/ factsheets /fs134/en/. 